http://dx.doi.org/10.1590/1678-4162-8824

Arq. Bras. Med. Vet. Zootec., v.68, n.6, p.1531-1538, 2016

\title{
Avaliação da interação biológica entre compósito de quitosana, colágeno e hidroxiapatita e tecido ósseo ovino
}

\author{
[Investigation of biological interactions of chitosan-collagen-hydroxyapatite composite with \\ bone tissue in sheep] \\ G.M. Marcondes ${ }^{1}$, F.S. Nóbrega ${ }^{1}$, L. Corrêa ${ }^{2}$, V.E. Arana-Chavez ${ }^{2}$, A.M.G. Plepis ${ }^{3}$, \\ V.C.A. Martins ${ }^{3}$, A.L.V. Zoppa ${ }^{1}$ \\ ${ }^{1}$ Faculdade de Medicina Veterinária e Zootecnia - Universidade de São Paulo - FMVZ USP - São Paulo, SP \\ ${ }^{2}$ Faculdade de Odontologia - Universidade de São Paulo - USP - São Paulo, SP \\ ${ }^{3}$ Instituto de Química de São Carlos - Universidade de São Paulo - IQSC USP - São Carlos, SP
}

\begin{abstract}
Fracture management poses a great challenge to large animal practitioners. Osteosynthesis alone is often insufficient to provide satisfactory outcomes in large animals; therefore, several research efforts have been made to investigate and develop bone substitutes capable of promoting bone regeneration. Chitosan-collagenhydroxyapatite composites constitute a promising alternative given their similar composition to bone. Six Santa Inês ewes were submitted to the creation of experimental $7 \mathrm{~mm}$ wide unicortical defects on the dorsomedial aspect of the proximal III/IV metacarpal bone diaphysis. Limbs were randomly selected for treatment with chitosan-collagen-hydroxyapatite composite or to serve as untreated controls. Biopsy fragments were collected from the bone/new bone or the bone/biomaterial interface (control and treated defects respectively) within 60 days of surgery; composite biocompatibility was assessed using light and scanning electron microscopy. Histomorphometric analysis under light microscopy revealed greater percentage of new bone tissue in control compared to treated defects $(80 \%$ and $63.5 \%$ respectively; $\mathrm{P}<0.05)$. No scar tissue formation, foreign body or chronic inflammatory reactions were observed. Scanning electron microscopy revealed invasion of the composite by new bone tissue. The chitosan-collagen-hydroxyapatite composite studied is biocompatible with bone and shows osteoconductive properties in sheep.
\end{abstract}

Keywords: ovine, biocompatibility, bone substitutes, chitosan, hydroxyapatite

\section{RESUMO}

As lesões em membros de grandes animais são um desafio para médicos veterinários, uma vez que somente a osteossíntese não garante resultados satisfatórios. Muitos pesquisadores vêm se dedicando ao desenvolvimento e estudo de substitutos ósseos produzidos de materiais naturais, como quitosana, colágeno e hidroxiapatita, que auxiliam na regeneração óssea. Seis ovinos fêmeas da raça Santa Inês foram submetidos a ostectomias unicorticais de sete milímetros de diâmetro na região proximal da superfície dorsomedial dos III/IV metacarpianos. Foi implantado compósito de quitosana, colágeno e hidroxiapatita em um membro torácico para avaliação da biocompatibilidade do material ao tecido ósseo ovino, e no membro contralateral foi reproduzida a mesma técnica, porém foi mantido sem preenchimento, como controle. Após 60 dias do procedimento cirúrgico, realizou-se biópsia óssea na área de interface entre biomaterial/osso (membro com compósito) e tecido neoformado/osso (membro controle), para realização de avaliação histológica do material não descalcificado, por meio de microscopia de luz e microscopia eletrônica de varredura. Na análise histomorfométrica, mediante microscopia de luz, foi possível identificar maior porcentagem de tecido neoformado em membro controle, quando comparado ao membro com compósito (80\% e 63,5\%, respectivamente; $P<0,05)$. Por meio da microscopia eletrônica de varredura, observou-se invasão da estrutura interna do compósito por tecido ósseo neoformado. Não houve formação de tecido cicatricial, reação de corpo estranho ou resposta inflamatória crônica nas amostras analisadas. Conclui-se que o compósito de quitosana, colágeno e hidroxiapatita, quando implantado em tecido ósseo ovino, apresenta biocompatibilidade e perfil osteocondutor.

Palavras-chave: ovinos, biocompatibilidade, substitutos ósseos, quitosana, hidroxiapatita

Recebido em 21 de outubro de 2015

Aceito em 20 de abril de 2016

E-mail: gemmarcondes@hotmail.com 


\section{INTRODUCTION}

Management of fractures with significant bone tissue loss poses a challenge for veterinarians (Freitas et al., 2008). A wide variety of biomaterials, including bone substitutes, have been developed to maximize bone regeneration and overcome potential limitations and complications related to the use of bone autografts (Pérez-Sánchez et al., 2010). Natural composites such as chitosan, collagen and hydroxyapatite, have similar chemical structure to bone and may therefore constitute an alternative for bone substitution (Amaral, 2006; Maeda, 2013).

The biological and biomechanical properties of biomaterials and bone tissue have been investigated in large animal species. In vivo and in vitro studies using bone defects as experimental models have been conducted in horses and sheep to evaluate bone-biomaterial interactions and the contribution of biomaterials to improved biomechanical resistance following trauma (Pearce et al., 2007; Selim, 2013; Uebersax et al., 2013; Von Rechenberg et al., 2013; Nóbrega, 2014).

Histological investigation of bone tissue responses to biomaterials using light and scanning electron microscopy is important for objective assessment of histological events and bone remodeling dynamics. Qualitative and quantitative data can be obtained with these methods (Petrizzi et al., 2007; Viateau et al., 2007; Von Rechenberg et al., 2013).

This study set out to investigate biological interactions between the III/IV metacarpal bone and chitosan-collagen-hydroxyapatite composite implants in sheep. Clinical and imaging assessments were performed, along with histological analysis of undecalcified material.

\section{MATERIALS AND METHODS}

This study was approved by the FMVZ/USP Ethics Committee for Animal Use (Protocol No. 2688/2012). Six healthy nonpregnant Santa Inês ewes aged 2-5 years and weighing $40-60 \mathrm{~kg}$ were used. Ostectomies were performed on the dorsomedial aspect of the proximal III/IV metacarpal bone diaphysis; limbs were randomly selected for treatment with composite or to serve as untreated controls. In the treated group, bone defects were filled with chitosancollagen-hydroxyapatite composite cylinders manufactured and provided by São Carlos Chemistry Institute, University of São Paulo, Brazil. Biomaterial cylinders were sterilized using oxyethylene and individually packed prior to use.

Animals were sedated with xylazine (Rompum ${ }^{\circledR}$, Bayer Saúde Animal, Brazil; 0.05mg. $\mathrm{kg}^{-1}$ ), induced with propofol (Propovan ${ }^{\circledR}$, Cristália, Brazil; $6 \mathrm{mg}^{\mathrm{kg}}{ }^{-1}$ ), and maintained with isoflurane in $100 \%$ oxygen (Isoforine, Cristália, Brazil). Postoperative medication consisted of sulfadoxine/trimethoprim (Borgal ${ }^{\circledR}$, Intervet, Brazil; 30mg. $\mathrm{kg}^{-1}$ ) once daily for five consecutive days and phenilbutazone (Equipalazone Injetável ${ }^{\circledR}$, Marcolab, Brazil; $4 \mathrm{mg} \cdot \mathrm{kg}^{-1}$ ) once daily for three days. Morphine sulphate (Dimorf Solução Injetável ${ }^{\circledR}$, Cristália, Brazil; $0.1 \mathrm{mg} . \mathrm{kg}^{-1}$ in $10 \mathrm{ml}$ of saline solution) was given once daily for two days via a lumbar epidural catheter.

Animals were placed in right lateral recumbency for bilateral ostectomy. The ostectomy site was determined using radiography. A $4 \mathrm{~cm}$ semicircular skin incision was made and the lateral digital extensor tendon, the lateral and the medial tendons of the common digital extensor muscle, were retracted laterally. The subcutaneous tissue was then separated and the periosteum incised to expose the proximal III/IV metacarpal bone diaphysis. Unicortical ostectomies were performed using an electric power drill (TRS, Synthes ${ }^{\circledR}$, Switzerland) and a $5 \mathrm{~mm}$ internal diameter trephine (Ortop ${ }^{\circledR}$, Brazil). A $5 \mathrm{~mm}$ wide full-thickness bone fragment was removed under constant irrigation with $1 \mathrm{~L}$ of $0.9 \%$ saline $/ 1.0 \mathrm{~g}$ amikacin sulphate solution (Isofarma ${ }^{\circledR}$ Brazil and Neofarma ${ }^{\circledR}$ Brazil respectively). Retracted tendons were repositioned and the periosteum and subcutaneous tissues sutured en bloc in a simple continuous fashion, using 2-0 poliglecaprone 25 (Caprofyl $^{\circledR}$, Ethicon ${ }^{\circledR}$, Brazil). The skin was closed in a simple continuous fashion using 2-0 monofilament nylon (Mononylon ${ }^{\circledR}$, Ethicon ${ }^{\circledR}$, Brazil). Surgical wounds were cleaned and a compression bandage applied.

Bone biopsy collection was performed within 60 days of surgery using the same preoperative 


\section{Avaliação da interação...}

anesthetic procedure and surgical approach. Ostectomy sites were located and biopsy specimens collected from the bone-bone defect or the bone-composite interface (control and treated limbs respectively) under constant irrigation. A $3.55 \mathrm{~mm}$ internal diameter trephine saw (INP ${ }^{\circledR}$, Brazil) and electric power drill were used to harvest $3.55 \mathrm{~mm}$ wide full-thickness fragments from the cis-cortex. Surgical procedures are shown in Figure 1.

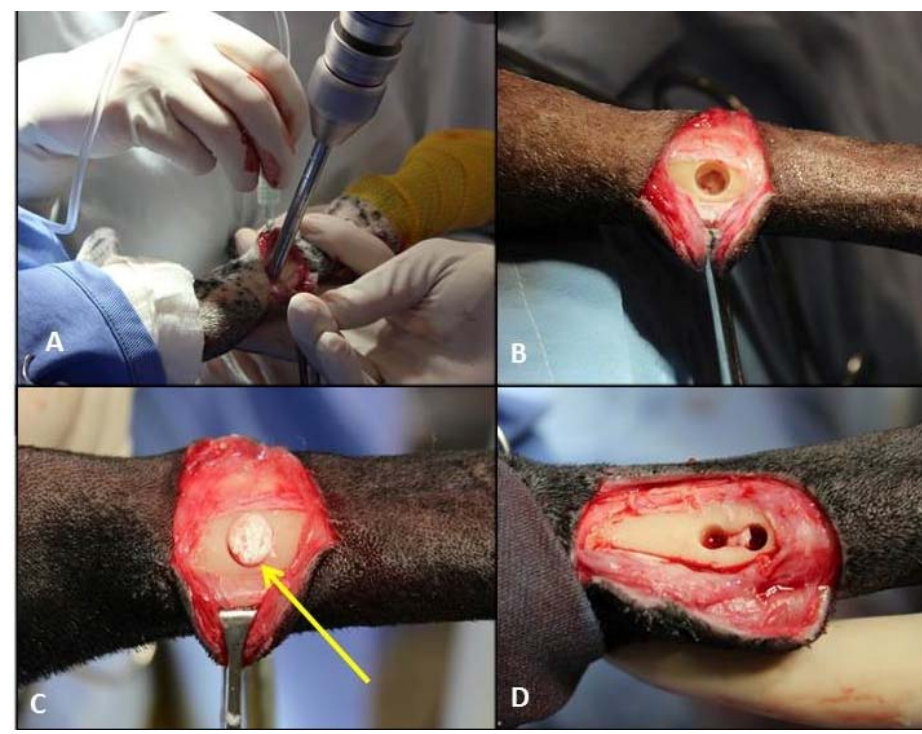

Figure 1. Surgical procedures. A: Bone cortex penetration using $5 \mathrm{~mm}$ internal diameter trephine. B: Bone surface appearance following full penetration of the cis-cortex and exposure of the medullary cavity. C: Gross appearance of the bone following biomaterial implantation; note complete filling of the bone defect with composite (yellow arrow). D: Gross appearance of the bone following collection of two biopsy fragments.

Biopsy specimens destined for light microscopy were fixed in $20 \%$ paraformaldehyde prior to processing for methyl methacrylate embedding; $0.5 \mathrm{~mm}$ thick sections were then cut from each tissue block and stained with Stevenel's Blue. New bone areas were quantified using the RGB color deconvolution plugin in Image $\mathrm{J}$ (WCIF Image $J^{\circledR} 1.37 \mathrm{a}$, National Institute of Health, USA) (Ruifrok and Johnston, 2008; Landini, 2010). Histological fields of view at $100 \mathrm{x}$ magnification were digitalized under a light microscope (DM2500, Leica ${ }^{\circledR}$, Germany) using a digitalization system composed of camera (DCF 295 , Leica ${ }^{\circledR}$, Germany) and morphometric data acquisition software (LAS, Leica ${ }^{\circledR}$, Germany). The plugin was then employed to separate the blue stain (bone matrix) from other colors in histological sections. Areas stained in blue were calculated and normalized to the total field area to return a percentage. Four to six slides per defect were quantified and mean percentages calculated using Microsoft Office Excel 2010 ${ }^{\circledR}$. Data were then exported into software (SPSS version 18.0, 2013) for statistical analysis. Quantitative variables were expressed as mean, median, standard deviation, minimum and maximum values and compared between treated and control limbs using the Wilcoxon test. The level of significance was set at $5 \%(\mathrm{P}<0.05)$. Slides were subsequently submitted to qualitative analysis.

Specimens destined for scanning electron microscopy were placed in vials containing fixation medium (25\% glutaraldehyde and $2.5 \%$ of $20 \%$ paraformaldehyde). Specimens were then dried in blotting paper, attached to small aluminum stubs with double-sided bonding tape and coated with a $25 \mathrm{~mm}$ layer of gold using SCD 050 sputter-coater (Bal-Tec ${ }^{\circledR}$, USA). Qualitative, morphological analysis was then performed using a scanning electron microscope (LEO 430, Oxford $^{\circledR}$, England) at $15 \mathrm{kV}$ accelerating voltage. Microscopic images were photographically documented. 


\section{RESULTS}

First intention healing was adopted in this study and sutures removed within 14 days of surgery. The selected surgical technique provided good access to the target area; good defect size standardization could be achieved using trephine saw.
Clearly visible bone/new bone interface facilitated biopsy collection procedures in this study. Biopsy specimen size could be adequately standardized using $3.55 \mathrm{~mm}$ trephine saw.

Histomorphometric analysis of decalcified material using light microscopy revealed greater percentage of new bone tissue in control compared to treated limbs $(\mathrm{P}<0.05$; Tab.1).

Table 1. Comparison of new bone fractions between treated and control limbs within 60 days of surgery

\begin{tabular}{llll}
\hline & Composite & Control & P* $^{*}$ \\
\hline Mean & 63.50 & 80.00 & 0.028 \\
Median & 65.50 & 80.00 & \\
Standard Deviation & 7.58 & 8.10 & \\
Minimum & 50.00 & 69.00 & \\
Maximum & 70.00 & 92.00 & \\
\hline
\end{tabular}

*P value; Wilcoxon test

Composite biocompatibility could also be confirmed using light microscopy. New bone tissue adjacent to pre-existing bone was observed in control limbs, along with several lacunae and medullary spaces filled with loose connective tissue; some areas of new bone also contained haversian canals. Immature bone trabeculae intermingled with loose cellular connective tissue and trabeculae, so as to form a continuum with pre-existing bone, were observed in treated limbs. Round-shaped, homogeneous, brownish exogenous material suggestive of composite remnants was also detected among newly formed bone trabeculae. Inflammatory infiltrate and multinucleated giant cells (i.e., foreign body reaction) were not documented (Fig. 2).

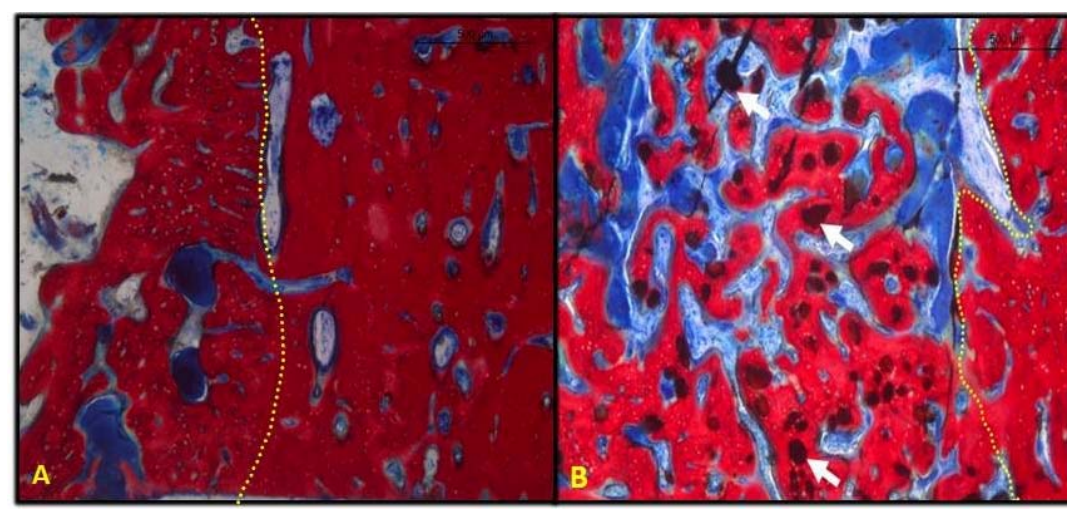

Figure 2. Photomicrograph (light microscopy) of control and treated defect biopsy specimens. A: Control Limb. Note new bone in contact with pre-existing, mature bone (to the left and right of the dotted yellow line respectively); haversian canals can also be observed. (Stevenel's Blue; 50X magnification). B: Treated Limb. Note new bone in contact with pre-existing, mature bone (to the left and right of the dotted yellow line respectively) and absence of foreign body reaction. Brownish exogenous material (white arrows) suggestive of composite remnants can also be observed. (Stevenel's Blue; 100X magnification).

Scanning electron microscopy revealed immature new bone tissue in contact with pre-existing bone in control defects, whereas small areas of new bone in direct contact with large areas of preexisting bone and composite were documented in treated defects. New bone formed in treated defects was similar in structure to new bone formed in control defects. The composite retained its original features, with mild signs of fragmentation and evidences of invasion by new bone tissue (Fig. 3). 


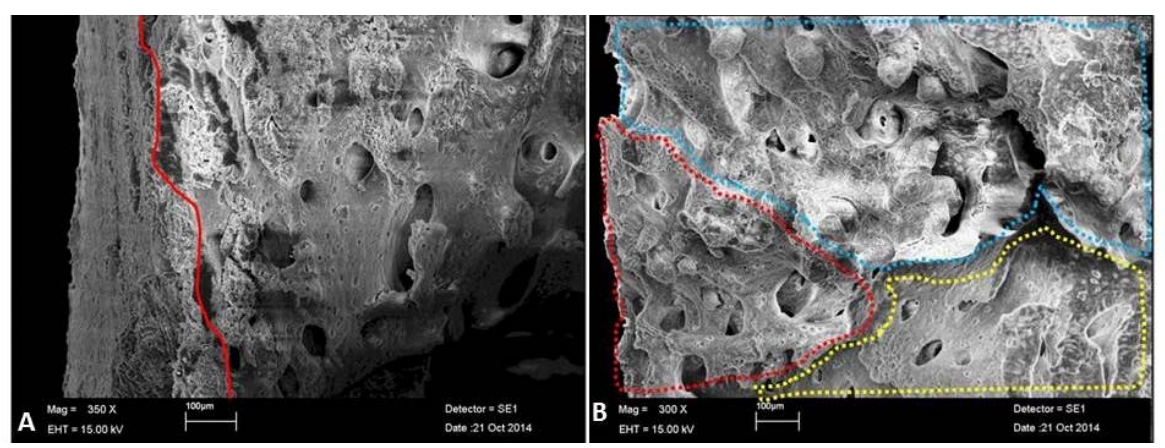

Figure 3. Photomicrographs (scanning electron microscopy) of control and treated defect biopsy specimens. A: Control Limb. Note pre-existing compact bone and new primary bone (to the left and right of the red line respectively); 350X magnification. B: Treated limb. Note newly formed bone tissue adjacent to pre-existing bone and composite material (areas encircled by red, yellow and blue lines respectively); 300X magnification.

\section{DISCUSSION}

The ostectomy model adopted in this study was adapted from trials involving round-shaped, metaphyseal defects in bones such as the humerus, femur, and metacarpals (Nuss et al., 2006; Petrizzi et al., 2007; Uebersax et al., 2013; Von Rechenberg et al., 2013). In a similar study by Petrizzi et al. (2007), experimental $4 \mathrm{~mm}$ bicortical bone defects created to investigate bone repair in the metacarpal diaphysis of sheep developed into critical bone defects that did not heal completely over the course of an 8-week experimental period. In agreement with data given by Petrizzi et al. (2007), authors of this study believe the selected model to be a safe, low morbidity alternative for bone healing investigation. Large animals are prone to fractures in areas with limited tissue coverage such as the metacarpus; therefore, this site was selected in the experimental model in this study despite lower regeneration rates compared to cancellous bone (Viateau et al., 2004; Nuss et al., 2006; Lopes and Markel et al., 2012). Lack of limited local soft tissue coverage was thought to facilitate surgical access in this and in previous studies involving round-shaped, unicortical, third metacarpal bone defects treated with Ricinus communis polyurethane in horses (Nóbrega, 2014).

Animals served as their own controls in this study. Satisfactory standardization, with reduced number of specific variables and increased statistical accuracy, has been reported in trials using similar experimental design (Babiker, 2013). Different from other trials, biopsy collection in this study did not require euthanasia and subjects were therefore spared (Viateau et al.; 2004; Nuss et al., 2006; Uebersax et al., 2013; Von Rechenberg et al., 2013).

Biopsy fragments were collected within 60 days of surgery; this time point is thought to be adequate for histological investigation of biocompatibility and osteoconduction following implantation of porous biomaterials in ovine bone (Nuss et al., 2006; Petrizzi et al., 2007; Plecko et al., 2012; Von Rechenberg et al., 2013).

Gross examination of treated limb biopsy specimens revealed incomplete composite resorption; the composite was clearly distinguishable from pre-existing bone and showed decreased resistance to manipulation at this time. Similar findings have been reported elsewhere (Bolson et al., 2005; Nóbrega, 2014). Further studies are warranted to investigate postimplantation mechanical resistance of this composite, which can be better assessed within 6 months of implantation in sheep (Nuss et al., 2006; Babiker, 2013).

In this study, histological analyses of undecalcified bone specimens under light and scanning electron microscopy were performed for qualitative evaluation of repair tissue in the presence and absence of the composite, and to investigate the occurrence of biomaterial-induced foreign body reaction (Atlan et al., 1999; Nuss et al., 2006; Viateau et al., 2007; Von Rechenberg et al., 2013). 
Scanning electron microscopy revealed preservation of bone microstructure in the presence of the composite. New bone formed in treated defects had similar microstructure to new bone in control defects and to ostectomy fragment bone. The absence of scar tissue suggests the composite did not induce foreign body reaction. Osteoconduction and biocompatibility between bone and calcium carbonate or hydroxyapatite have been previously documented in sheep and rabbits respectively (Atlan et al., 1999; Chang et al., 2000).

Structural preservation with mild signs of degradation within 60 days of implantation suggests bioresorption behavior of the composite in sheep. However, resorption takes longer to occur compared to new bone formation, as previously reported in a study evaluating the interaction of Ricinus communis polyurethane with bone tissue in horses (Selim, 2013).

Scanning electron microscopy of treated defects revealed interconnections between new and preexisting bone and invasion of composite pores by new bone tissue; similar findings have been reported in studies using hydroxyapatite-based composite (Matsuda et al., 1995). Fusion of new bone, composite and pre-existing bone in treated defects in this study confirms the osteoconductive potential of the composite employed.

Light microscopy revealed significantly greater percentage of new bone in control compared to treated limbs, again confirming incomplete resorption of the biomaterial, which is thought to contribute to lower new bone formation (SpinNeto et al., 2008; Selim, 2013; Nóbrega, 2014). In contrast, greater percentage of new bone formation has been reported following treatment of experimental bone defects with demineralized human bone matrix, platelet rich plasma alone or platelet rich plasma combined with cancellous bone autografts (Oakes et al., 2001; Silva et al., 2009). The absence of inflammatory infiltrates or multinucleated giant cells in this study suggests the lack of a foreign body reaction and supports composite biocompatibility (Martino et al.; 2005;
Thein-Han and Misra, 2009; Babiker, 2013). The absence of foreign body reaction following subcutaneous implantation of similar biomaterial has been reported in rats (Amaral, 2006).

Findings in this study support previous data on biocompatibility and osteoconduction following application of chitosan scaffolds (Wang et al., 2002) or different hydroxyapatite-based composites (Maeda, 2013) to the tibia of rabbits. However, lack of biocompatibility has been documented in rats treated with several chitosanbased products, and may reflect unreliable product origin, lack of purity and low porosity (Spin-Neto, 2008). Foreign body reactions following implantation of demineralized bovine bone matrix in the femur of rabbits have also been described (Carneiro et al., 2005). In this study, proper extraction and processing of natural composite components was thought to contribute to biocompatibility with ovine bone tissue.

\section{CONCLUSION}

Light and scanning electron microscopy findings in this study support osteoconductive properties and biocompatibility of the chitosan-collagenhydroxyapatite composite with ovine bone tissue. This biomaterial could therefore serve as an ancillary treatment in fractures associated with extensive bone tissue loss in large animals.

\section{ACKNOWLEDGEMENTS}

This research project was funded by Fundação de Amparo a Pesquisa do Estado de São Paulo (FAPESP 2012/23629-9).

The authors thank Prof. Silvia Renata Gaido Cortopassi, graduate students Cínthia Lima Lhamas, Nicole Fidalgo Paretsis, Danielle Cristinne Bacarelli, Luis Eduardo Stevanato de Almeida, Bruno Bregnanin Pedron, and Douglas do Carmo Alonso, and undergraduate student Thamires Shizue Panassol Mizobe for their assistance in surgical procedures. We also thank Maria Célia Ramos Bellenzani for critical review of this manuscript. 


\section{REFERENCES}

AMARAL, M.B. Citotoxicidade in vitro $e$ biocompatibilidade in vivo de compósitos a base de hidroxiapatita, colágeno e quitosana. 2006. 98f. Dissertação (Mestrado em Bioengenharia) Instituto de Química de São Carlos, Universidade de São Paulo, São Carlos, SP.

ATLAN, G.; DELATTRE, O.; BERLAND, S. et al. Interface between bone and nacre implants in sheep. Biomaterials, v.20, p.1017-1022, 1999.

BABIKER, H. Bone graft materials in fixation of orthopaedic implants in sheep. Dan. Med. J., v.60, p.1-19, 2013.

BOLSON, J.; SCHOSSLER, J.E.; ORNES, R.C. et al. Análise clínica, radiológica, macroscópica e histológica do úmero de codornas domésticas (Coturnix japonica), submetido ao implante de poliuretana derivada do polímero de mamona (Ricinnus communis). Ciênc. Rural, v.35, p.1123-1130, 2005.

CARNEIRO, E.; GARCIA, R.B.; OLIVEIRA, R.C. et al. Microscopic and radiographic analysis of the effect of particle size demineralized bovine cancellous bone matrix on the repair of the bone defects in femur of rabbits. J. Appl. Oral Sci.,v.13, p.157-162, 2005.

CHANG, B.S.; LEE, C.K.; HONG, K.S. et al. Osteoconduction at porous hydroxyapatite with various pore configurations. Biomaterials, v.21, p.1291-1298, 2000.

FREITAS, S.H.; DÓRIA, R.G.S.; MENDONÇA F.S. et al. Aspecto radiológico de heteroenxerto ósseo cortical fragmentado na reparação de falhas ósseas em coelhos. Braz. J. Vet. Sci., v.15, p.107-110, 2008.

LANDINI, G. Color deconvolution using Image $J^{\circledR} \quad 2010 . \quad$ Available in: $<$ http://www.dentistry.bham.ac.ik/landinig/softw are.html>. Accessed in: 23 June 2014.

LOPES, M.J.; MARKEL, M.D. Bone biology and fracture healing. In: AUER, J.A.; STICK, J.A. (Eds.). Equine surgery. St Louis: Elsevier Saunders, 2012. p.1025-1039.

MAEDA N.T. Avaliação da neoformação óssea em tíbia de coelho utilizando cúpula de hidroxiapatita associada a diferentes biomateriais. 2013. 91f. Dissertação (Mestrado em Ciências) - Instituto de Pesquisas Energéticas e Nucleares, São Paulo, SP.

MARTINO, A.; SITTINGER, C.M.; RISBUD, M.V. Chitosan: a versatile biopolymer for orthopaedic tissue-engineering. Biomaterials, v.26, p.5883-5890, 2005.

MATSUDA, M.; KITA, S.; TAKEKAWA, M. et al. Scanning electron and light microscopic observations on the healing process after sintered bone implantation in rats. Histol. Histopathol.,v.10, p.673-679, 1995.

NÓBREGA, F.S. Avaliação da interação biológica entre o polímero de poliuretana de mamona acrescido de carbonato de cálcio e tecido ósseo de equinos. 2014. 156f. Tese (Doutorado em Ciências) - Faculdade de Medicina Veterinária e Zootecnia, Universidade de São Paulo, São Paulo, SP.

NUSS, K.M.R.; AUER, J.A.; BOOS, A. et al. An animal model in sheep for biocompatibility testing of biomaterials in cancellous bone. BMC Musculoskel. Dis.,v.7, p.1-14, 2006.

OAKES, D.; LEE, C.; LIEBERMAN, J. An evaluation of the osteoinductive potential of human demineralized bone matrices in an attymic rat femoral defect model. In: ANNUAL MEETING OF ORTHOPEDIC RESEARCH SOCIETY, 47., 2001, San Francisco. Proceedings... São Francisco: ORS, 2001. p.2528.

PEARCE, A.; RICHARDS, R.G.; MILZ, S. et al. Animal models for implant biomaterial research in bone: a review. Eur. Cell. Mater., v.13, p.1$10,2007$.

PÉREZ-SÁNCHEZ, M.J.; RAMÍREZGLINDON, E.; LLEDÓ-GIL, M. et al. Biomaterials for bone regeneration. Med. Oral Patol. Oral Cir. Bucal., v.15, p.517-522, 2010.

PETRIZZI, L.; MARISCOLI, M.; VALBONETTI, L. et al. Preliminary study on the effect of parenteral naloxone, alone and in association with calcium gluconate, on bone healing in an ovine "drill hole" model system. BMC Musculoskel. Dis., v.8, p.1-9, 2007.

PLECKO, M.; SIEVERT, C.; ANDERMATT, D. et al. Osseointegration and biocompatibility of different metal implants: a comparative experimental investigation in sheep. BMC Musculoskel. Dis., v.13, p.1-12, 2012. 
RUIFROK, A.C.; JOHNSTON, D.A Quantification of histochemical staining by color deconvolution. Anal. Quant. Cytol. Histol., v.23, p.291-299, 2008.

SELIM, M.B. Avaliação estrutural do osso terceiro metacarpiano equino frente à implantação de biopolímero à base de mamona. 2013. 122f. Dissertação (Mestrado em Ciências) - Faculdade de Medicina Veterinária e Zootecnia, Universidade de São Paulo, São Paulo, SP.

SILVA, P.S.A.; CARLO, R.J.; SERAKIDES, R. et al. Plasma rico em plaquetas associado ou não ao osso esponjoso autógeno no reparo de falhas ósseas experimentais. Ciênc. Rural, v.39, p.129134, 2009.

SPIN-NETO, R. Desenvolvimento e aplicação de biomateriais a base de quitosana para reconstrução óssea: avaliação radiográfica $e$ histológica. 2008. 131f. Dissertação (Mestrado em Odontologia) - Faculdade de Odontologia de Araraquara, Universidade Estadual Paulista Júlio de Mesquita Filho, Araraquara, SP.

SPIN-NETO, R.; PAVONE, C.; FREITAS, R.M. et al. Biomateriais a base de quitosana com aplicação médica e odontológica: revisão de literatura. Rev. Odontol. UNESP, v.37, p.155$161,2008$.
THEIN-HAN, W.W.; MISRA, R.D.K. Threedimensional chitosan-nano hydroxyapatite composite scaffolds for bone tissue engineering. Biomed. Mater. Devices, v.61, p.41-44, 2009.

UEBERSAX, L.; APFEL, T.; NUSS, K.M.R. et al. Biocompatibility and osteoconduction of macroporous silk fibroin implants in cortical defects in sheep. Eur. J. Pharmacol. Biopharm., v.85, p.107-118, 2013.

VIATEAU, V.; GUILLEMIN, G.; BOUSSON, V. et al. Long-bone critical size defects treated with tissue-engineering grafts: a study on sheep. J. Orthop. Res., v.12, p.741-749, 2007.

VIATEAU, V.; GUILLEMIN, G.; YANG ,C. et al. A technique for creating critical-size defects in the metatarsus of sheep for use in investigation of healing of long-bone defects. Am. J. Vet. Res., v.65, p.1653-1657, 2004.

VON RECHENBERG, B.; GÉNOT, O.R.; NUSS, K. et al. Evaluation of four biodegradable, injectable bone cements in an experimental drill hole model in sheep. Eur. J. Pharmacol. Biopharm., v.85, p.130-138, 2013.

WANG, X.; JIANBIAO, M.A.; YINONG, W. et al. Bone repair in radii an tibias of rabbits with phosphorylated chitosan reinforced calcium phosphate cements. Biomaterials, v.23, p.41674177, 2002. 